\title{
May I wash you? - Learning through experiencing vulnerability and controlled trials
}

\author{
Ragna Ingeborg Engelien , Solveig Struksnes \\ Department of health, care and nursing, Gjøvik University College, Gjøvik, Norway.
}

Received: September 1, 2014

Accepted: October 13, $2014 \quad$ Online Published: October 20, 2014

DOI: $10.5430 /$ jnep.v5n1p26

URL: http://dx.doi.org/10.5430/jnep.v5n1p26

\begin{abstract}
Background: Clinical skills training related to personal hygiene causes anxiety and stress among nursing students due to the fact that they use each other as "patients". To justify this learning activity more knowledge about the students' experiences and learning outcome is needed.
\end{abstract}

Aim: To describe how nursing students experience clinical skills training using one another as "patient".

Method: Qualitative descriptive design. The sample was 187 nursing student in the first year of study, previous of their first clinical practice in nursing homes. Data collection was performed with questionnaires with open-ended questions. Inductive content analysis was performed.

Results: The students' experiences being "patient" was condensed into 12 subcategories, underlying the four categories: Tention related to the role play, physical and mental vulnerability, assessment of the care and learning through bodily experience. Descriptions about being "nurse" ended in 12 subcategories an the four categories: Awareness of being in a role, to gain experience of being a nurse, turning one's attention to the other and feeling prepared to clinical practice.

Conclusions: Performing and coping the challenging learning activity seems to increase the students' self-confidence related to the coming clinical practice.

Key Words: Nurse education, Clinical skills training, Patient simulation, Personal hygiene

\section{Introduction}

Nursing education in Norway is regulated by the National Curriculum, ${ }^{[1]}$ with the programme including 50 weeks of clinical studies. The Quality Reform of higher education has implications for how colleges and universities develop and facilitate an optimal learning environment. ${ }^{[2]}$ In Norway students carry out 10 weeks of clinical practice in nursing in the first year. It is crucial to the quality of professional studies that the teaching at educational institutions is relevant, and occurred through interaction with the professional field. ${ }^{[3]}$ Nursing students should achieve a certain level of confidence and precision before they practice nursing with patients. ${ }^{[4,5]}$ Educational institutions organize internal clinical practice (ICP) to enable students to better develop skills related to basic care before taking part in clinical practice.

Nurse Educator programs often use role play as a learning activity associated with manual nursing skills and procedures. ${ }^{[4,5]}$ Students use each other as "patients" in some exercises, though training models and mannequins are also used. The purpose of these simulated exercises is that par-

\footnotetext{
* Correspondence: Ragna Ingeborg Engelien; Email: ragna.engelien@hig.no; Address: Department of health, care and nursing, Gjøvik University College, Gjøvik, Norway.
} 
ticipants will acquire insight into complex relationships and connections in a specific context. ${ }^{[6]}$ Since the students' inexperience poses a risk to patients, they are put in simulated or impersonated processes or conditions that they will encounter in practice. ${ }^{[7]}$

Skills training in nursing education can be linked to a long tradition of "master-apprentice learning", as well as descriptions of the development from novice to expert. ${ }^{[8]}$ The pedagogical principles underlying simulation methodology may be partially linked to the learning theory of constructivism. ${ }^{[9]}$ According to Fenwick ${ }^{[10]}$ and Woolfolk, Pettersson, ${ }^{[11]}$ the simulation methodology is also inspired by ideas from experimental learning and a view of learning as an active process. ${ }^{[9]}$

This study is about the use of a "sponge bath" for bedridden patients prior to clinical practice in nursing homes. The students prepare by reading about the procedure, and video is used to demonstrate the procedure before the exercise. Three students work together, so that they all experience being in the role of the "nurse", the "assistant" and the bedridden "patient". This simulation exercise can cause anxiety and frustration among students; therefore, it is argued that different types of mannequins or "patient simulators" can be used instead. On this basis, it was desirable to investigate how students experienced this learning procedure.

\section{Purpose and objectives}

The purpose of this study was to describe nursing students' experiences with conducting skills training with each other as "patients". The research questions were related to the students' experiences of playing the role of both patient and nurse.

\section{Method}

The study has a qualitative, descriptive design as a consequence of the purpose concerning students' experiences related to a simulated nursing situation. Data collection was conducted in the spring of 2013, using questionnaires with open-ended questions, and a content analysis was ${ }^{[12]}$ used to capture the experiences, reflections and attitudes of the informants' descriptions. ${ }^{[13]}$ The context was the college's simulation lab, a "ward" with 21 patient beds and adjoining rooms and facilities.

The sample was "purposive". ${ }^{[14]}$ In accordance with the study's purpose, the informants were students in the first year of nursing education. They represented both genders, were between ages of 19 to 50 years and had varying experience with the health-care services.

The exercise was compulsory, and both oral and written information about the study were given a week before the exercise. It was emphasized that it was voluntary to answer the questionnaire, anonymity was assured ${ }^{[12]}$ and the submitted form was considered as consent to participate.

The following questions were asked: How did you experience being the "patient"? How did you experience being the "nurse"? Did you learn anything through this exercise that may be useful in your clinical studies? If "yes", what did you learn? If "no", why not?

The questionnaire was two-sided, with one A-4 page for answering questions related to each of the roles. The forms were placed on the bedside tables, and were filled out immediately after the exercise and placed in a box at the end of the session.

\section{Data analysis}

Out of 196 students, 187 replied (95\%). The questionnaires were numbered, and the descriptions were entered into a table to make them more manageable. An inductive content analysis was conducted according to Graneheim and Lundman, ${ }^{[13]}$ and the text was thoroughly read to get a sense of the whole, and to identify units of analysis in the text that responded to the purpose of the study. Units of analysis were divided into meaning units: 683 units about being a "patient" and 508 about the role of being a nurse. The material was then condensed, but the core was preserved according to Graneheim and Lundman. ${ }^{[13]}$ The condensed text was abstracted and named, or "coded". These codes were grouped and became the basis for subcategories, while comparison, grouping and the reduction of subcategories were the next step. The analysis resulted in four categories describing students' experiences of being a "patient" and four categories describing the experience of being a "nurse". A further interpretation and abstraction of the content resulted in two themes. According to Graneheim and Lundman, ${ }^{[13]}$ the theme captures the core of content analysis, and is described as an interpretation of the underlying meaning of the text, referred to as the "latent content". ${ }^{15,16]}$

\section{Findings}

The findings are presented in a figure to ease readability, and all categories and subcategories are subsequently described with quotes to illustrate.

\subsection{Students' experiences of being a "patient"}

The findings are described in four categories and 12 subcategories.

\subsubsection{Tension related to the role play}

The category describes the informants' experiences with an unfamiliar learning procedure.

\section{Dreaded the situation}

Informants dreaded that fellow students would wash them. It was "a little scary with regard to exposure of the private 
body parts" (12). Others found that the implementation of the exercise went better than expected, and it was not as uncomfortable or bad as they had anticipated. Some thought it was "nice" to be a patient in this exercise or "fun and delicious to be cared for" (46).

\begin{tabular}{|c|c|c|}
\hline \multirow{2}{*}{$\begin{array}{l}\mathbf{P} \\
\mathbf{A}\end{array}$} & $\begin{array}{l}\text { THEME: LEARNING THROUGH EXPERIENCING VI } \\
\text { SUBCATEGORIES }\end{array}$ & CATEGORIES \\
\hline & $\begin{array}{l}\text { Dreaded the situation } \\
\text { Tested their limits } \\
\text { Entered a role }\end{array}$ & Tention related to the role play \\
\hline T & $\begin{array}{l}\text { Felt helplessness } \\
\text { Dreaded bodily exposure } \\
\text { Felt the handiness of the nurse }\end{array}$ & Physical and mental vulnerability \\
\hline $\begin{array}{l}\text { I } \\
\text { E }\end{array}$ & $\begin{array}{l}\text { Discovered the significance of flow } \\
\text { Perceived safety, security and safeguarding } \\
\text { Felt the impact of the nurse's actions }\end{array}$ & Assessment of the care \\
\hline $\begin{array}{l}\mathbf{N} \\
\mathbf{T}\end{array}$ & $\begin{array}{l}\text { Became conscious of how the patient may feel } \\
\text { Reflected on one's own performance } \\
\text { Discovered relevance to professional nursing }\end{array}$ & Learning through bodily experience \\
\hline \multirow{4}{*}{$\begin{array}{l}\mathbf{N} \\
\mathbf{U} \\
\mathrm{R} \\
\mathrm{S} \\
\mathrm{E}\end{array}$} & $\begin{array}{l}\text { Knew the patient as peer } \\
\text { Experienced utility of discussing on the way } \\
\text { Experienced to immerse into the situation }\end{array}$ & Awareness of being in a role \\
\hline & $\begin{array}{l}\text { Realized the importance of planning } \\
\text { Experienced challenges of dealing with another human } \\
\text { Trained taking control of the situation }\end{array}$ & To gain experience of being a nurse \\
\hline & $\begin{array}{l}\text { Noticed the importance of taking into account the patient } \\
\text { Felt significant to an other person } \\
\text { Experienced feeling responsible for the patient }\end{array}$ & Turning one's attention to the other \\
\hline & $\begin{array}{l}\text { Perceived useful learning } \\
\text { Experienced importance of cooperation } \\
\text { Discovered challenges in real life }\end{array}$ & Feeling prepared to clinical practice \\
\hline & SUBCATEGORIES & \multirow[t]{2}{*}{ CATEGORIES } \\
\hline & THEME: LEARNING THROUGH CONTROLLED TRI & \\
\hline
\end{tabular}

Figure 1: Theme: Learning through experiencing vulnerability and controlled trials

\section{Tested their limits}

It was experienced as "uncomfortable that fellow students went so far into my comfort zone" (30). An informant describes that she had asked to see her supervisor in advance of the session because of anxiety about show herself to fellow students in her underwear. The student was encouraged to participate, but with a swimsuit in place of underwear. After the class the student expressed happiness that she did not skip class, as it was "good to know my limit of being close to other people in an intimate situation" (113).

\section{Entered a role}

To carry out a role-play felt positive for some, while others considered it "somewhat unpleasant to be treated as sick when I was well" (128). The situation did not feel completely "natural" when "I was actually able to take care of myself" (128). The role-play could also be perceived as a situation in which it was difficult "to let go because it's not for real" (28).

\subsubsection{Physical and mental vulnerability}

This section describes the informants' experiences with being washed in bed.

\section{Felt helplessness}

The informants said it felt humiliating and degrading not to have control over their situation. "It was annoying to be so helpless" (101). One could feel very "small" when others stood over them, and "unsafe about what the nurse should do" (89). This also gave them a feeling of "losing control" (101).

\section{Dreaded bodily exposure}

It was expressed as being uncomfortable and degrading to "be washed", but also that it was more comfortable than feared. Feeling humiliated in a "care situation" and the feeling of nudity was emphasized. "It felt nasty to be so in need of care that someone has to brush your teeth and disgusting to have the toothbrush far back in your mouth" (116).

\section{Felt the handiness of the nurse}

The experience of the situation depended on the handiness of the fellow student. Some described it as feeling "hardhanded, cold fingers, which gradually improved" (54). Others had experiences with "gentle hands that made me safe" (126).

\subsubsection{Assessment of the care}

This section describes how the informants perceived the impact of the "nurse" actions and behaviour, as well as the 
relationship between the two.

\section{Discovered the significance of flow}

The "nurses" had difficulty doing several things at once. "My body quickly becomes cold after someone has gone over me with the cloth and not dried me with the towel yet. It is more comfortable when the nurse takes her time, but is quick to dry me the towel" (105). The exercise was described as "complicated" and more than "just using the cleaning cloth and hygiene" (72). Planning and the "flow" of the procedure were highlighted as being significant for the patient. "The sheet was not exactly the way it should be, there was much back and forth and it felt lumpy" (72). The nurses were perceived as "clumsy", but it "was fun and educational to see how others planned and carried out the procedure" (5). Experiencing the importance of good planning was described by others as "It was helpful that she had arranged everything in advance so I did not have to wait' (56).

\section{Perceived safety, security and safeguarding}

Information was important for how the "patients" felt that they were safe and cared for. If the "nurses" told what they were going to do, it was "never unsafe to entrust the care to them" (98). Getting little information produced a feeling of insecurity. "When tilted from side to side without being prepared is scary" (98). It was described as significant that the "nurses" were calm and not stressed. "Nurses" who enabled good communication and had a sense of humour was mentioned by several. Some also experienced security because "the nurse showed that she had some knowledge" (8). The experience of being "sick" and "to feel and recognize the care gives a good feeling and confidence" (32).

\section{Felt the impact of the nurse's actions}

The participants felt how it was to be handled and washed. Many descriptions dealt with the fact that they became cold during the procedure if they were not thoroughly dried and covered with the duvet. It was also pointed out that it is important to be aware of "how hard the nurse used the cloth" (139). Some experienced being washed "well in depth", while others felt the nurses showed uncertainty and did the procedure "half-way" (11). "I did not feel clean afterwards because the nurses were too cautious" (11).

\subsubsection{Learning through bodily experiences}

This section describes the students' reflections on what they learned about having the role of being a patient.

\section{Became conscious of how the patient may feel}

The exercise helped to enable the informants to familiarize themselves with the patient's situation. "We learn to become good nurses with understanding and care. Each case is individual, but we get an idea of what can be pleasant or unpleasant" (32). When one was "washed" by a stranger, an anxiety about being exposed was revealed, which can be difficult to understand without having been in the situation. "The sense of what it is to lie almost naked is a good experience compared to remembering that one should not expose the patient" (19).

\section{Reflected on one's own performance}

The experience of being the "patient" created an awareness of its own insofar as how nurses in general should act in the nursing role: "Being a patient during this exercise was helpful in terms of how I care for patients" (96). The situation was perceived as useful even if the "patient" had practiced earlier. "I became freshened up a bit since I have worked in health-care before" (56).

\section{Discovered relevance to professional nursing}

It was reported that the experience contributed to learning "how to deal with other people" (29) and "to show humility" (57) when entering the clinical field. "It is important for the patient that you take your time, thus enabling the patient to do what he or she is capable of doing, because you feel quite helpless when lying in bed" (38).

Experiencing various techniques, order, the knack of getting it right, posture and hygiene encouraged reflections on what it takes to provide quality nursing care. "One must think about the patient's feelings, and not what is easiest for the nurse. How we handle the patient's arms and legs when we wash is so important" (44).

\subsection{Students' experiences of being a "nurse"}

The findings are described in four categories and 12 subcategories.

\subsubsection{Awareness of being in a role}

This section describes the reports about role-play as a process in which the informants varied from a strong awareness of the situation to immersing themselves in the role.

\section{Knew the patient as peer}

It was a bit unaccustomed and uncomfortable having to wash a fellow student in bed. Some found that this contributed to making the situation "artificial", while others thought it was nice to care for a fellow student. However, there was some uncertainty attached to where the "patient's" comfort zone was. The awareness of being in a role-play had some impact on the performance to begin with. "It probably made me more whimsical and giggly than I otherwise would have been" (108). As two informants claimed, "It is easier to be a real nursing assistant" $(63,72)$.

\section{Experienced utility of discussing on the way}

It was described as positive to receive feedback from fellow students. "I got good feedback from the patient, and I saw and learned things I had not quite understood by just reading 
about it" (30). Other students got comments on specific aspects of the "nurse's" handiness if one was rough or relaxed, or exposed the "patient".

\section{Experienced being immersed in the situation}

It was hard to maintain the role throughout the care. The situation was perceived at first as somewhat "artificial" compared to an authentic situation. "The focus was sometimes a bit blurred because in reality the patient was a fellow student" (35). Still, several informants reported that they felt stressed, and sympathized with the patient. "The patient trusted me, and I felt that I had to prove that I was reliable" (23).

\subsubsection{To gain the experience of being a nurse}

This section describes the informants' statements about being aware of the nursing challenges associated with washing a patient in bed.

\section{Realized the importance of planning}

The participants gained experience with how to conduct a procedure with regard to planning, to retrieving equipment, on where to start and how to keep track of everything. "There is a lot of detail and it's harder than you think" (4). Some informants were aware that "it was good to have all equipment in good working order and available under the care, and that it was easy to forget what should take place (82). This procedure "is not as easy as it looks" was a general comment.

It was considered important to have "flow" in the care, to avoid too much unrest and to have some "back and forth for the patient" (93). To forget things because of nervousness and uncertainty was also frequently described. The informants' thought more about hygiene "and all you have to remember with clean and unclean" (54). Training in keeping clean objects from becoming unclean was also associated with planning. It was perceived as "difficult to keep the bed dry if planning is poor" (76).

\section{Experienced the challenges of dealing with another hu- man being}

The simulated situation yielded insight into how to "in detail use hands in the washing and caring of a patient" (22). It "feels a bit clumsy the first time" (87). The descriptions of handiness also told about touching a patient while simultaneously protecting "everything concerning the patient" during the procedure. It was "difficult to know how rough they should be" $(19,94,103)$. The learning activity enabled the informants to try out different ways by asking for feedback. Hence, the care could "be adapted to the patient" (123). Specific challenges mentioned were the techniques of how to hold the patient's legs and arms during the washing, and how to perform oral care.

\section{Trained and taking control of the situation}

It was described as "fun" to be responsible or to "take control of the care situation" (10). The reports were partly about delegating tasks to the assistant and making decisions along the way.

"It was fun to be in charge, where I made the decisions. I felt like a person with a lot of knowledge, when the assistant asked me what she should do" (53). To "get a sense of the leadership role" (84) and to practice recalling a procedure was described as being useful. Throughout the exercise, the informants became aware of "being distinct in terms of providing information to the patient and assistant" (133).

Some point out the significance of first having the role of a patient, nurse or assistant. Being a "nurse" as the last role was considered "the best". The student then "got to see how the two others did it first", and could not figure out what she "thought was best" (106).

\subsubsection{Turning one's attention to the other}

This section describes the participant's experiences of interaction with the patient during the exercise.

\section{Noticed the importance of taking the patient into ac- count}

Several informants describe the importance of finding out how to proceed to make "the best possible situation" (110) for the patient. "The patient has their trust in you, you must show that you can be trusted by taking into account the patient's special needs, being patient and communicating with the patient about his or her needs" (14).

\section{Felt significant to another person}

The joy of feeling useful to another person was expressed by several informants. It was important to have a good dialogue with the "patient"; I could practice how to talk to the patient "so he or she got a positive experience" (57). By being caring and considerate, the informants felt to be "important caregivers", and "it felt really good to be able to help another human being" (162).

\section{Experienced feeling responsible for the patient}

Being in charge of the procedure the students acquired insight into the responsibility of being a nurse. "It is you who should be able to this. If you do something wrong, you feel like you are alone with it" (14). It was expressed that it might be difficult to communicate in a distinct way, and to give concrete messages to the assistant and the patient. "I got the opportunity to give some messages and to feel that I had control of the situation" (23).

\subsubsection{Feeling prepared for clinical practice}

This section describe assumptions about how the training can be useful in future clinical studies.

\section{Perceived useful learning}

ISSN 1925-4040 E-ISSN 1925-4059 
The informants experienced how to care for a patient in the best possible way, and get a sense of "how the future will actually be" (62). For some, the experience provided an awareness of what skills it is important to have to achieve more training. "I felt that I had forgotten much of the procedure, but I carried it out OK. I must learn to have more faith in myself" (102). Some found "new and better ways to perform activities" (37). Others were concerned with the exercise situation itself, and that they "had to stop and reflect on the next step" (61). First and foremost, the experience of learning was linked to being conscious of the need to be confident and have "control" over the situation. To help achieve this, the "necessity of exercise, exercise, exercise ..." was stressed (108).

\section{Experienced the importance of cooperation}

The practical advantages of having two nurses wash a patient in bed was mentioned, "especially in heavy care" (139). "When you have two caregivers working together, we can also help each other to remember the correct order of the procedure" (139). Collaborating with another student was considered to be a good preparation for clinical practice. "I was trying to decide and to put everything in order[...] to cooperate with the assistant. It gives more responsibility - it's more like real work" (6). Being the one to make decisions was perceived as being "scary" the first time. Some felt that they did not like to "command" others, but noticed that the exercise gave them an insight into how this could be done in a good way. "It's good to feel self that I can take responsibility in a situation with another 'nurse'; it makes me become more confident in my role" (97).

\section{Discovered challenges in real life}

Not all students were confident about the benefits of simulation, e.g. "it feels a little strange or artificial, I think it's probably different out there" (153). It was commented that one must do this in practice to learn, but that it is also nice to be able to try out the procedure by "taking your time, and using trial and error" (77). It is reassuring to try it out on fellow students first, and then to "hopefully not be as clumsy with a real patient" (119). The exercise was described as a "taste" of everyday life for three years, but one part of a complete sponge bath that students dread remains to be discovered. "I may have to get used to conducting intimate hygiene in a real life situation, in which the patient is very contaminated with urine and stool and so on" (143).

\section{Discussion}

The purpose of the study was to describe how nursing students experienced being the "patient" and the "nurse" in a simulated nursing situation. The discussion is related to the two main research questions: How did the students experience being the "patient" and the "nurse", and did they learn anything presumably useful to their impending clinical prac- tice?

Students' descriptions of being in the role of the patient ended with the theme, "Learning through experiencing vulnerability". Being in the nursing role is about; "Learning through controlled trials".

\subsection{Learning through experiencing vulnerability}

The role-play is described as unnatural and artificial. As a "patient", you are treated as being sick without being so. Yet, the students experienced feelings of helplessness and vulnerability because others have control over the situation. These experiences correspond with studies in which actual patients express helplessness and dependence related to being unable to take care of themselves. ${ }^{[17,18]}$ The students assume that the experience enables them to understand the patients' situation, and to develop empathy. It is debatable as to whether this kind of experience is required in order to develop empathy. Can empathy also be obtained through the theoretical questioning of patient situations? ${ }^{[19]}$ Travelbee $^{[20]}$ points out that the ability of empathy must be developed through life experience and through meeting with various patients. Thus situated, young students with a limited life experience may find it difficult to achieve empathy. Consequently, it is an important task for educators to create learning situations that help to facilitate experiences that simulate being a patient.

To have one's comfort zone crossed was perceived as threatening and unpleasant, as our self-esteem is affected by our bodily perception. ${ }^{[21]}$ The body has a social, political and cultural aspect that can affect people's view of their own body, Bjørk and Breievne ${ }^{[22]}$ point out. In our Western culture, the ideal of beauty is related to a slim and well-trimmed body, so being naked and requiring assistance with one's personal hygiene can be perceived as a violation and threat to a person's integrity. ${ }^{[23,24]}$ For example, nurses should ensure the patient's dignity by protecting the patient against vulnerable situations. ${ }^{[25]}$ The students' perception of nudity was dependent on whether the "patient" was shielded by his or her fellow students, which was perceived as an expression of respect from the fellow student.

Handiness or "hands as a communication channel",[26] was significant for the experience of being washed by others. Students found it annoying and threatening to be cooled or to be "dealt with" in a clumsy manner. Karoliussen $^{[24]}$ claims that the nurse's hands can convey tranquility, strength, safety, security, closeness, warmth and trust.

To feel cared for, to get information about what nurses do, and that the nurse did not rush and was in a good mood were all accentuated by the students. These experiences can be related to how real patients experience care. Kvåle ${ }^{[27]}$ shows that the patient's experience of care is related to the health professional's proficiency in dealing with the situation. This 
is about how nurses inform, care and show respect and humor. By having the experience of being a simulated patient, students can more easily put themselves into the patient's situation.

\subsection{Learning through controlled trials}

Being in a role-play was challenging with respect to "living into" the situation, which can be linked to the ability to engage and look past what distinguishes the situation from reality. ${ }^{[28]}$ Some lived in both the patient's and the nurse's role, with personality type, background and experience influencing how well the individual was able to immerse themselves in the simulation. It is almost impossible to create a sufficiently realistic scenario for some individuals. $^{[28]}$ In the simulation it is one and the same situation, with apparently identical outer frames, which is perceived and interpreted differently by the participants. ${ }^{[29]}$ This can lead to different learning outcome, but also to constructive reflections.

It was experienced as uncomfortable to cross fellow students' intimate zone, and has previously been described that nurses are afraid, bothered and embarrassed in their first experience with handling another's body. ${ }^{[25]}$ It felt useful to discuss the simulation with fellow students during the rehearsal situation, with the purpose of the trial being to make it an evidence-based procedure. This type of ICP presumably contributing to a faster achievement of the necessary competence, ${ }^{[30]}$ and provides a basis for utilizing the time in clinical practice more effectively.

Trying out the role of the nurse awakened the students, as several discovered that to conduct a sponge bath is more complex than assumed, and had stress reactions. To master the complexity of a relatively simple procedure depends on a student's cognitive, affective and psychomotor abilities. ${ }^{[30]}$ Psychological factors that can trigger stress are the feeling of insufficient knowledge, in addition to being exposed to high demands or expectations in the situation. ${ }^{[31]}$ The students' descriptions of the challenges related to the trial correspond with Bjørk and Kirkevold's ${ }^{[30]}$ description of a low level in the development of skills. In order to move from this level to a level where the skill is performed with great precision, students undergo various developmental stages. ${ }^{[8]}$ Repetition is required to integrate the different actions in a sponge bath and provide professional comprehensive care.

Several students intended to combine good communication with a correct implementation of the procedure, though few achieved this. Conducting a sponge bath for the first time forces the nurse to have a strong focus on the proper performance of the procedure and less of a focus on the patient's experience and emotions. The situation can then give a sense of power, powerlessness, vulnerability and feelings of inadequacy, ${ }^{[32]}$ even in a role-play.

Responsibility for the "patient" and rejoicing at helping him or her was described, even though the situation was simulated, and the students felt useful and satisfied when providing good care. Mercy, charity, compassion and a "decentric motivation of caring" are fundamental values in nursing. ${ }^{[33]}$ Nurses must respect the individual's life and values, and nursing should be based on caring and a respect for human rights. ${ }^{[34]}$ Despite the fact that it is a role-play, the students experienced the need for having sufficient knowledge to avoid any incorrect treatment of the patient. This sense of responsibility may encourage the students to not only feel a responsibility for their own learning, but also to emphasize propriety in clinical practice.

To some extent, nursing skills can be learned in simulation laboratories, but the contextual, relational and social aspects

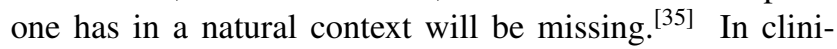
cal practice, the students' actions obviously have far greater consequences than in the simulation laboratory. In modern society, a scholastic and individually centred view on learning have devoted too little attention to the learning of resources that occurs in participating in a working environment. ${ }^{[36]}$ Halland $^{[37]}$ claims that "the road to learning involves a number of aspects of social and cultural nature that hinder or promote the learning process, and thus the outcome of the learning process" (p. 27). These conditions are significant parts of the conducting of practical nursing. As a result, one can never be sure of the learning effect of instruction and practice in the simulation laboratory, and there has been a limited amount of research on the transfer value of simulation in clinical practice. ${ }^{[38,39]}$ McCaughey and Traynor $^{[40]}$ found that nursing students in their last study year regarded simulation as a method that prepared them for the transition from student to nurse, which generally promoted patient safety. Blum and Parcells ${ }^{[41]}$ conclude that that one still has no reason to claim that simulation helps students develop their skills in this area.

Although a lot of effort has been put into making realistic situations in the simulation laboratory, there will always be a need in a natural context for a technical and emotional adaptation to a real situation. ${ }^{[42,43]}$ It should be endeavored to organize learning activities in educational institutions so that students' actions have consequences for others. In this way, they can learn from their own decisions. ${ }^{[33,37]}$ With this in mind, it may be appropriate "to use one another" as learning objects in a learning situation. Students will then have the opportunity to give each other feedback on the impact their actions have.

\subsection{Students' assumptions about the exercise ben- efits of practical studies}

The students claim that they learn something about how to "handle" other people through "feeling with their body" how it is to be patient, though whether this can be attributed to the development of empathy is hard to say. The students' perceptions are relatively unambiguous as regards that this 
experience, which will make them better able to carry out similar procedures on others. It is argued that empathy facilitates the development of mutual trust and mutual understanding, and hence is a fundamental quality in nursing. ${ }^{[19]}$ According to Harder, ${ }^{[43]}$ students' simulation training may increase their knowledge and skills, thereby improving communication. Experiencing the nursing role was linked to having control of the situation, leading the care, making decisions and communicating their knowledge to their "assistant", and was perceived as educational. After graduating, nurses should have the competence to "lead and manage nursing practice in relation to individual patients and their families and recognize and acknowledge a professional and personal responsibility for their actions and evaluations". ${ }^{[1]}$ The simulated training is clearly considered to be a preparation for taking responsibility in clinical practice. Simulation as an educational method may contribute to improving self-esteem in nursing students, ${ }^{[4]}$ as students face learning situations with different feelings, attitudes, skills and understanding. The prerequisite of the participants in relation to the learning process is described as the student's physical, mental, social and professional opportunities and problems in various areas. ${ }^{[4]}$ Khalaila $^{[46]}$ describes how simulation-based training reduces anxiety among students, while Gates, Parr and Hughen ${ }^{[47]}$ found that the learning situation can create stress and anxiety. Stress can cause significant performance drops until a stable mastery level has been reached. ${ }^{[48]}$ If the degree of a perceived stress situation may affect learning outcomes, it will likely affect the perception of how the student assesses the utility of the learning activity. Nevertheless, despite the fact that the students were exposed to a highly challenging situation, the majority perceived that the exercise was not as "dangerous" as feared.

\subsection{Methodological implications}

The sample is considered as being representative of students in the first year of study for bachelor nursing since it was very high response rate $(95 \%)$. This high response rate may reflect the fact that the informants were in a mandatory learning situation, and consequently experienced "undue pressure" to fill in the forms. However, information on voluntary participation, anonymity and the consequences of participation meets the requirements of good research ethics. ${ }^{[12]}$ Additionally, it was emphasized that no students should feel watched over when the questionnaires were delivered.

Data collection was conducted using questionnaires with open-ended questions, which is not common in qualitative methods. An argument for the use of questionnaires for the collection of qualitative data is that the participant is free to answer in their own words. Moreover, reliability can be enhanced by all the interviewees answering the same question under the same conditions. ${ }^{[49]}$ On the other hand, using questionnaire eliminates the opportunity to ask follow-up questions, and the answers may be less detailed. Some of the informants in this study had written cues, while others had long and rich descriptions and reflections.

\section{Summary}

The study describes students' experiences of using one another as "patients" in the simulation exercise of washing a patient in bed, which felt challenging, both mentally and physically. The students described the exercise as being educational, and emphasized the importance of experiencing the patient role. The role of the nurse was a useful experience with regard to having responsibility for the "patient" and the "assistant". To implement and master this learning situation appears to contribute to an increased confidence in meeting the practice field. The exercise increased awareness in terms of what they need to work on before and during guided practice.

\section{References}

[1] Kunnskapsdepartementet. Rammeplan for sykepleierutdanning 2008. Available from: http://www.regjeringen.no/upload/

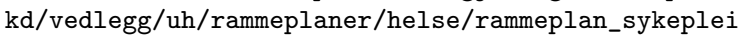
erutdanning_08.pdf.

[2] Helse- og omsorgsdepartementet. St.meld. nr. 25 (2005-2006): Mestring, muligheter og mening. Framtidas omsorgsutfordringer. 2006.

[3] Kunnskapsdepartement. Meld. St. 13 (2011-2012). Available from http: //www.regjeringen.no/nb/dep/kd/dok/regpubl/s tmeld/2011-2012/meld-st-13-20112012.html?id=672836

[4] Fagermoen, M.S., Sykepleie i teori og praksis - et fagdidaktisk perspektiv. 1993, Oslo: Universitetsforlaget. 182.

[5] Studdy, S.J., M.J. Nicol, and A. Fox-Hiley, Teaching and learning clinical skills, Part 2-Development of a teaching model and sched- ule of skills development. Nurse Education Today. 1994; 14(3): 186193. http: //dx . doi .org/10 .1016/0260-6917 (94)90080-9

[6] Leigh, E. and L. Spindler, Simulations and games as chaordic learning contexts. Simulation \& Gaming. 2004; 35(1): 53-69. http: //dx.doi.org/10.1177/1046878103252886

[7] Morton, P.G., Using a critical care simulation laboratory to teach students. Critical care nurse. 1996; 17(6): 66-69.

[8] Benner, P., From novice to expert: excellence and power in clinical nursing practice. 1984, Menlo Park, Calif.: Addison-Wesley. 307.

[9] Rodgers, D.L., High fidelity patient simulation: A descriptive white paper report. 2007.

[10] Fenwick, T.J., Expanding conceptions of experiential learning: A review of the five contemporary perspectives on cognition. Adult Education Quarterly. 2000; 50(4): 243-272. http://dx.doi.org $/ 10.1177 / 07417130022087035$

[11] Woolfolk, A.E., et al., Pedagogisk psykologi. 2004, Trondheim: Tapir akademisk forl. 480. 
[12] The Nordic Nurses Federation. Ethical guidelines for nursing research in the Nordic countries. 2014.

[13] Graneheim, U.H. and B. Lundman, Qualitative content analysis in nursing research: concepts, procedures and measures to achieve trustworthiness. Nurse Education Today. 2004; 24(2): 105112. PMID: 14769454 http://dx.doi.org/10.1016/j.nedt. 2003.10.001

[14] Polit, D.F. and C.T. Beck, Nursing research: generating and assessing evidence for nursing practice. 2012, Philadelphia, Pa.: Wolters Kluwer Health.

[15] D Wamboldt, B., Content analysis: method, applications, and issues. Health care for women international. 1992; 13(3): 313321. PMID:1399871 http://dx.doi .org/10.1080/073993392 09516006

[16] Kondracki, N.L., N.S. Wellman, and D.R. Amundson, Content Analysis: Review of Methods and Their Applications in Nutrition Education. Journal of Nutrition Education and Behavior. 2002; 34(4): 224-230. http://dx.doi.org/10.1016/S1499-4 046 (06) 60097-3

[17] Boge, J. and K. Kristoffersen, Elderly patients want to be as independent as possible the first postoperative weeks, and they want to be nursed and massaged by caring nurses with humour. Vård i Norden. 2002; 22(1): 47-51.

[18] Ugland, R.L., Ren og velstelt?, in Det medisinske fakultet. 1998, Universitetet i Oslo: Oslo

[19] Williams, J. and T. Stickley, Empathy and nurse education. Nurse Education Today. 2010; 30(8): 752-755. PMID:20381220 http: //dx.doi.org/10.1016/j.nedt.2010.01.018

[20] Travelbee, J., Mellommenneskelige forhold i sykepleie. 1999, Oslo: Universitetsforlaget. 287.

[21] Bengtsson, J., А̊ forske i sykdoms-og pleierfaringer: livsverdensfenomenologiske bidrag. 2006: Høyskoleforlaget.

[22] Bjørk, I. and G. Breievne, Kropp og velvære, in Grunnleggende sykepleie, bind 2. 2011, Gyldendal Akademiske. 371 - 397.

[23] Randers, I. and A. Mattiason, The experiences of elderly people in geriatric care with special reference to integrity. Nursing Ethics. 2000; 7(6): 503-519. PMID:11221392 http://dx.doi.org/10. $1177 / 096973300000700606$

[24] Karoliussen, M., Sykepleie - tradisjon og forandring: en humanøkologisk tilnærming. 2002, Oslo: Gyldendal akademisk. 287.

[25] Lawler, J. and A.-M. Smith, Bak skjermbrettene: sykepleie, somologi og kroppslige problemer. 1996, Oslo: Ad Notam Gyldendal. 235.

[26] Kristoffersen, I., Det gode stellet, in Den omtenksomme sykepleier: artikkelsamling i forbindelse med at Diakonissehjemmets sykepleierhøgskole Haraldsplass er 75 år i mai 1993, K. Martinsen, Editor. 1993, Tano: Oslo. 131-143.

[27] Kvåle, K., Den omsorgsfulle sykepleier - slik pasienter ser det. Vård i Norden. 2006; 26(1): 15-19.

[28] Rettedal, A., Illusion and technology in medical simulation: If you cannot build it, make them believe, in Using Simulations for Education, Training and Research, P. Dieckmann, Editor. 2009, Pabst: Lengerich. p. 202-214.

[29] Dieckmann, P., D. Gaba, and M. Rall, Deepening the Theoretical Foundations of Patient Simulation as Social Practice. Simulation in Healthcare. 2007. 2(3): 183-193. PMID:19088622 http: //dx.doi.org/10.1097/SIH.0b013e3180f637f5

[30] Bjørk, I.T. and M. Kirkevold, From simplicity to complexity: developing a model of practical skill performance in nursing. Journal of Clinical Nursing. 2000; 9(4): 620-631. PMID:11261145 http://dx.doi.org/10.1046/j.1365-2702.2000.00328.x

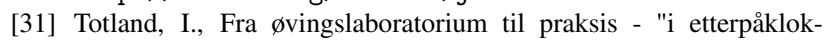
skapens lys": om sykepleierstudenters erfaringer og opplevelser fra praksis sett i relasjon til det å ha lært praktiske ferdigheter i $\varnothing \mathrm{v}$ ingslaboratorium i forkant av praksisstudiene. 2007, Universitetet $\mathrm{i}$ Oslo: Oslo.
[32] Lillemoen, L., Verdier og verdispørsmål i sykepleie: Behovet for systematisk etisk refleksjon, in Verdi og verdighet: Etikk i praksis, E. Skærbæk and L. Lillemoen, Editors. 2013, Cappelen Damm Akademisk: Oslo. PMID:22918061

[33] Kristoffersen, N.J. and P. Nortvedt, Relasjonen mellom sykepleier og pasient, in Grunnleggende sykepleie b. 1, N.J. Kristoffersen, F. Nortvedt, and E.-A. Skaug, Editors. 2011, Gyldendal akademisk: Oslo. p. 83-133.

[34] International Council of Nurses. ICNs etiske regler for sykepleiere. 200028.02.

[35] Brynildsen, G., Ikke bare enkle prosedyrer...: Læring og utvikling av praktiske ferdigheter i en naturligsetting. 2007, Oslo.

[36] Nielsen, K. and S. Kvale, Praktikkens læringslandskab: at lære gennem arbejde. 2003, København: Akademisk Forlag.

[37] Halland, G., Læring gjennom stimulerende samspill: Veiledning, vurdering og ledelse. 2004, Bergen: Fagbokforlaget. 354.

[38] Bjørk, I., Changing conceptions of practical skill and skill acquisition in nursing education. Nursing Inquiry. 1997; 4(3): 184195. PMID:9335821 http://dx.doi.org/10.1111/j.1440-1 800.1997.tb00098.x

[39] Alteren, J. and I. Bjørk, Studentens læring av praksiske ferdigheter i modellavdeling og klinikken; et utforskende design. Vård i Norden. 2006; 82(26): 25-30.

[40] McCaughey, C.S. and M.K. Traynor, The role of simulation in nurse education. Nurse Education Today. 2010; 30(8): 827832. PMID:20483188 http://dx.doi.org/10.1016/j.nedt. 2010.03 .005

[41] Blum, C.A. and D.A. Parcells, Relationship between high-fidelity simulation and patient safety in prelicensure nursing education: a comprehensive review. The Journal of nursing education. 2012; 51(8): 429-435. PMID:22624562 http://dx.doi.org/10.3928 /01484834-20120523-01

[42] Collins, J. and R. Harden, AMEE Medical Education Guide No. 13: real patients, simulated patients and simulators in clinical examinations. Medical Teacher. 1998; 20(6): 508-521. http://dx.doi.o $\mathrm{rg} / 10.1080 / 01421599880210$

[43] Harder, B.N., Use of simulation in teaching and learning in health sciences: a systematic review. The Journal of nursing education. 2010; 49(1): 23-28. PMID:19731886 http://dx.doi.org/10. 3928/01484834-20090828-08

[44] Foronda, C., S. Liu, and E.B. Bauman, Evaluation of simulation in undergraduate nurse education: An integrative review. Clinical Simulation in Nursing. 2013; 9(10): e409-e416. http://dx. doi.org $/ 10.1016 / j$. ecns. 2012.11.003

[45] Hiim, H. and E. Hippe, Læring gjennom opplevelse, forståelse og handling: en studiebok i didaktikk. 1998, Oslo: Universitetsforlaget. 288.

[46] Khalaila, R., Simulation in nursing education: An evaluation of students' outcomes at their first clinical practice combined with simulations. Nurse education today. 2014; 34(2): 252-258. PMID:24060462 http://dx.doi.org/10.1016/j.nedt. 2013 .08 .015

[47] Gates, M.G., M.B. Parr, and J.E. Hughen, Enhancing nursing knowledge using high-fidelity simulation. Journal of Nursing Education. 2012; 51(1): 9. PMID:22085206 http://dx.doi.org/10.3928 /01484834-20111116-01

[48] Lauvås, P., G. Handal, and A. Ytreland, Veiledning og praktisk yrkesteori. 2000, Oslo: Cappelen akademisk. 339.

[49] Weimand, B.M., et al., 'Left Alone with Straining but Inescapable Responsibilities:' Relatives' Experiences with Mental Health Services. Issues in Mental Health Nursing. 2011; 32(11): 703710. PMID:21992262 http://dx.doi.org/10.3109/0161284 0.2011 .598606 